have been divorced from the barren question of whether he intended a reversion or a remainder. Yet this distinction was obscured by the fact that the court felt obliged to classify the future interest before it could settle the issue before it.

The effect of the doctrine of Doctor v. Bughes has been to cause the courts considerable embarrassment in this branch of the law of future interests. While short shrift has been made of the touchstone of intention, the difficult problems of construction introduced and their extension to personal as well as real property have served only to increase litigation. It may be that the solution to these difficulties lies in a return to the arbitrary but more predictable English version of worthier title. Intention can be furthered as much by clear rules of guidance at the drafting stage as by elastic rules of construction when litigation arises. The New York experience seems to warrant a step in this direction. Still, if intention is to be sought at all, the approach submitted has the merit of stating it in terms that are realistic. The Uniform Law Institute has proposed a third alternative giving effect to the literal words of the disputed limitation. ${ }^{33}$ Both the latter solution and the discarded English view recognize the value of a clear and predictable rule, although this is necessarily at the expense of being somewhat arbitrary.

\title{
CONSTIITUTIONALITY OF STATE EQUALIZATION OF PROPERTY ASSESSMENTS IN ILLINOIS
}

In two decisions involving the assessment and taxation of real property, ${ }^{1}$ the Illinois Supreme Court recently upheld the constitutionality of the Butler Program ${ }^{2}$ of state equalization which attempts to effect "full value" assessments in the administration of the Illinois general property tax. A definite ruling on the program's validity in relation to personal property taxation was avoided, however, by the United States Court of Appeals for the Seventh Circuit $^{3}$ on an appeal from a district court decision which had found the program, as it is presently administered, to be unconstitutional, particularly as applied in the taxation of personal property. ${ }^{4}$

The enactment of the Butler Program reforms in 1945 marked an important

${ }_{33}$ "When any property is limited, in an otherwise effective conveyance inter vivos, in form or in effect, to the heirs or next of kin of the conveyor, which conveyance creates one or more prior interests in favor of a person or persons in existence, such conveyance operates in favor of such heirs or next of kin by purchase and not by descent." Proposed Uniform Property Act \$ 15. But for an able defense of the present rule, see Professor Warren's article in 2 U. of Toronto L.J. $3^{89}$ (1938).

${ }^{2}$ People v. Wasson Coal Co., 403 Ill. 30,85 N.E. 2 d 182 (x949); People v. Albert, 86 N.E. 2 d 237 (1949).

2 Ill. Rev. Stat. (1947) c. I20, $\$ \S 627^{-} 32$.

${ }^{3}$ In the Matter of Chicago Railways Co., I75 F. 2 d 322 (C.A. 7 th, 1949).

4 In re Chicago Railways Co., 79 F. Supp. 989 (IIl., I948). 
step toward the goal of equity and consistency in the enforcement of the Illinois general property tax. ${ }^{5}$ In accord with the principle of uniformity, the general property tax requires that all property situated in the same taxing district be taxed at a uniform rate and assessed in proportion to its value. ${ }^{6} \mathrm{By}$ far the most troublesome aspect of such an ad valorem tax is the process of assessment. To insure the uniform apportionment of the aggregate amount of tax liability, it is essential that assessors apply a uniform standard of valuation to all property subject to a given tax. Disparities in valuation are bound to occur, however, because of individual differences in judgment among assessors as well as the variation in rules between different assessment jurisdictions. As a practical remedy for such disparities the Illinois property tax law provides for an equalization process by which assessed valuations, initially made, in most cases ${ }^{7}$ by township assessors, are later revised by county boards of review. The responsibility of these boards is to discover inequities and omissions throughout their respective counties and to "equalize" the original assessments either by classes of property or by geographic areas in order to achieve countywide uniformity of assessment. ${ }^{8}$ The Butler Program legislation carries the equalization process one step further by providing for a state-wide equalization of county assessments as revised or equalized by the county boards of review.

'Allen, Full-Value Assessment Program in Illinois, 3I Bull. Nat'l Tax Ass'n II7 (I946); Bresee, The Butler Tax Assessment Bills, 35 Ill. B.J. 58 (I946); Property Tax Reform in Illinois, Business Conditions I- -4 (Fed. Res. Bank of Chicago, Aug. I945); An analysis of the Butler Program, a report prepared by the Tax Committee of the Ill. State's Attorneys Ass'n in collaboration with the Ill. Dept. of Rev. (I946).

${ }^{6}$ Ill. Const. Art. 9, §§ I, 9; Sherlock v. Village of Winnetka, 68 Ill. 530, 535 (I873); cf. Jensen, Property Taxation in the United States $\mathrm{r} 60$ (I93I). The uniformity rule has been vehemently criticized by scholars and official bodies for its failure to reach the various types of modern wealth and its demoralizing effect upon the taxpayer. Cummings, Amending the Revenue Article of the Illinois Constitution, 29 Chi. Bar Record 259 (1948); Sears, Constitutional Revision and Party Circle Bills, I4 Univ. Chi. L. Rev. 200, 207 (r947); Ill. Const'I Conv. Bull. 239 (I920). Most of the states have abandoned the strict uniformity rule and have adopted a taxing system based on some form of property classification whereby the tax burden is adjusted as between different classes of property according to their varying capacities to pay and to evade taxes. The general belief with respect to Illinois has been that the uniformity provision of the Illinois Constitution precludes a classification system. Bachrach v. Nelson, 349 Ill. 579, I82 N.E. 909 (I932), criticized in Illinois Requirement of Uniformity in Taxation, 33 Ill. L. Rev. 57, 60- 64 (x938). Recent dicta of the Illinois Supreme Court, however, are leading some authorities to the view that some form of legislative property classification might be upheld under the present constitutional provision. Compare Cummings, supra, at 26I, 267; Joint Legislative Committee to Investigate Tax Problems, Report to Governor Dwight H. Green (March 2, 1945); The Constitutionality of Classification of Property for Tax Purposes in Illinois, 36 Ill. L. Rev. 796 (I942); Uniformity Required by the Illinois Constitution, 30 Ill. B.J. 300 (I942).

7 IIl. Rev. Stat. (I947) c. I20, $\$ \S 483,489$. In Cook County, however, which is one of the exceptions to this general set-up, there is an elected full-time county assessor with a staff of full-time deputies, and a two member board of appeals which performs the functions of a board of review. Ill. Rev. Stat. (I947) c. I20, $\$ \S 487,492$.

8 Ibid., \$ 589 . 
The need for state-wide equalization stems from the universal habit of local assessors of undervaluing property, ${ }^{9}$ a custom originating as an attempt to minimize local contributions to state revenue. ${ }^{10}$ This custom has continued in Illinois in spite of the fact that full value assessment has been a statutory requirement since 1927.11 Wide disparities in local levels of fractional assessment in Illinois resulted in an inequality in the distribution of state taxes during the period when the state levied a property tax. ${ }^{12}$ Although all property throughout the state was subject to a uniform, nominal tax rate, discrimination occurred since the effective rate of taxation varied according to the level of assessment valuation which prevailed in the various counties. Similar discriminations occurred with respect to property located in taxing districts overlapping two or more counties ${ }^{13}$ and in the case of state-assessed but locally-taxed property. ${ }^{14}$ Variance in local ratios of assessment also rendered ineffective the nominally uniform ceiling tax rates and bond limitations applicable to particu-

'Ill. Const'l. Conv. Bull. 233 (r920); Property Tax Reform in Illinois, Business Conditions 3 (Fed. Res. Bank of Chicago, Aug. 1945).

${ }^{10}$ Leland, The Classified Property Tax in the Uniled States 18 (rg28).

II During the period $1898-1927$, the tax statutes prescribed a uniform debasement of assess. ments at one-fifth, one-third, and finally one-half of full value. Allen, Full Value Assessment Program in Illinois, 3 I Bull. Nat'l Tax Ass'n II6, II ( 1946 ). Since I927, however, the Illinois Revenue Act has stipulated a standard of "fair-cash value." This has been quite generally understood to require full value assessment in spite of contrary practices. Anderson v. City of Park Ridge, 396 Ill. 235, 245, 72 N.E. 2d 210, 215 (I945); People v. St. Louis Bridge Co., 357 Ill. $245,252-53$, xgr N.E. 300,303 (I934); People v. Gillespie, $35^{8}$ Ill. 40, 47 , I92 N.E. 664 , 667 (1934) (semble); III. Dept. of Rev., Illinois Assessors' Manual 14, I6I (r944).

12 The state itself does not currently rely upon the general property tax for its own support, using in its stead the sales tax, technically known as the retailer's occupational tax. III. Rev. Stat. (I947) C. I20, $\$ \S 440-53$. However, the general property tax still represents, as it always has, the main source of revenue for some 14,500 local governments in Illinois. Ill. Dept., of Rev. Mllinois Assessors' Manual 90 (1944).

${ }_{13}$ For example, in People v. Allyn, 393 Ill. I $_{54}, 65$ N.E. 2 d 392 (I946), the complainant was held liable for three and one-half times the amount in municipal taxes charged against similar property receiving identical services and situated within the same village but in another county merely because of the variance in assessment ratios used by the two counties: 75 per cent in Cook County and 2I per cent in Lake County.

I" Capital stock of certain domestic corporations and railroad operating property are assessed by a state agency, currently the Department of Revenue. In Mobile and Ohio R. Co. v. State Tax Commission, 374 IIl. 75, 28 N.E. 2d 100 (1940), criticized in Labovitz, Uniformity in Illinois Property Tax, 29 TII. B.J. 249, 278-82 (I94I), and in Equalization in Railroad Assessments in Illinois, 35 IIl. L. Rev. 766 (r94I), the Illinois Supreme Court held that the uniformity rule required that such property be taxed on a basis of state-wide equalization of assessment ratios regardless of any disparity from local levels of assessment in the particular counties where the property was to be taxed. This meant, for example, that the operating property of the Mobile and Ohio in 1938 was uniformly assessed at $34 \frac{1}{2}$ per cent of its full value while adjoining homes, farms, and other property in counties through which the railroad operated were taxed on the basis of $76,68,66,65,53,40$, and $3 \circ$ per cent of their full value. Thus in all but one of these counties locally assessed property in this case was subject to higher effective rates of taxation than the state-assessed railroad property. 
lar classes of taxing bodies, ${ }^{15}$ and created discrimination in the distribution of state relief funds. ${ }^{16}$

In addition, the de facto power of local assessors to fix the level of assessment enabled assessing agencies to act as quasi-budget officers for all taxing districts in their respective jurisdictions, ${ }^{17}$ and, in addition, to affect the distribution of the tax-load outside of their jurisdictions. The latter inconsistency arose under the practice of equalizing state-assessed but locally-taxed property on the basis of the state-wide weighted average of local assessment ratios. ${ }^{18}$ The classic instance of this inconsistency occurred in I943 when the Cook County assessment ratio was suddenly increased from 37 per cent, a ratio which had been in effect since the late twenties, to 75 per cent. Because of the tremendous influence of Cook County in the determination of an average weighted by the value of local property, the state-wide average jumped from 3 I to 54 per cent. The extra-jurisdictional effect of the local decision in Cook County was to increase the tax load carried by state-assessed properties and to decrease the load carried by other taxpayers in districts outside Cook County, although its effect within Cook County was the reverse. ${ }^{19} \mathrm{~A}$ decision to decrease the Cook County ratio would, of course, have resulted in the opposite state-wide shift in the relative burden of local taxes.

It was the announcement in 1943 by the Cook County Assessor of his intention to construe literally the statutory full-value assessment requirement which directed public attention to the foregoing problems of fractional assessment ${ }^{20}$ and led to the enactment in 1945 of the Butler Program reforms. ${ }^{21}$ The back-

${ }^{15}$ These fiscal restrictions are expressed in terms of the aggregate assessed value of local property. Maximum tax extensions and bond issues therefore varied from county to county according to the level of the local assessment ratio. Joint Legislative Tax Committee to Investigate Tax Problems, Report to Governor Dwight H. Green (March 2, 1945).

${ }^{16}$ Eligibility of local governments for state relief depends in part upon the level of local property tax rates for specified purposes. But since the level of tax rates is largely dependent upon the magnitude of the local assessment ratio, the amount of tax extension necessary to qualify under a uniform tax rate requirement varied in accordance with the local assessment ratio. Ibid. Allen, Advantages to School Districts of Full-Value Assessment Programs, 32 Bull. Nat'l Tax Ass'n 194, I96 (r947).

${ }^{17}$ Stiles, "Full Fair Cash Value" in the r945 Illinois Equalization Program, 32 Bull. Nat'1 Tax Ass'n 34 (1946); Ill. Tax Comm'n, Tax-Rate Limits and Assessment Ratios: 1925-1940, at $I$ ( 1940$)$.

${ }^{18}$ See note 14 supra.

${ }^{19}$ Bresee, The Butler Tax Assessment Bills, 35 Ill. B.J. 58, 60 (I946). These relationships were further altered when the Butler Program took effect in I 946 . "The result was a relative shift of tax liability: to local assessments in the Downstate counties, from such assessments in Cock County. State assessments therefore secured some relief from the added load that had been placed upon them Downstate in r943 and lost something of their gain of that year in Cook County." Property Taxes in Tllinois, Illinois Property Tax News Letter No. 5, at ro (Ill. Dept. of Rev., Prop. Tax Div., Feb. I949).

${ }^{20}$ Joint Legislative Committee, op. cit. supra note 15.

21 These reforms are embodied in Senate Bill 229, Ill. Rev. Stat. (I947) c. I20, \$\$ 627-32; and Senate Bill $3 \pi_{4}$, Ill. Rev. Stat. (1947) c. I20, $\$ 643^{2}$ (as amended in 1947 by House Bill 
bone of this program is Senate Bill 229, which directs the Department of Revenue to "lower or raise the total assessed value of property in any county ... so that such property will be assessed at its full fair cash value."22 To accomplish this objective the department is required to analyze local assessments in relation to property transfer and appraisal data and to certify appropriate percentages, known as multipliers, to the county clerks, ${ }^{23}$ whose duty it is to apply these multipliers to the locally assessed valuations as revised and corrected by the boards of review. ${ }^{24}$ Assessments of capital stock of certain domestic corporations and of railroad operating property remain a responsibility of the Department of Revenue, but they are to be certified to county clerks at full value. ${ }^{25}$ In calculating tax rates and extending taxes, the county clerk is to use assessed valuations as equalized or confirmed by the department. ${ }^{26}$ In addition, the statute provides that the "full fair cash value of all property ... after giving effect to equalization by the Department shall be the assessed valuation for all purposes of taxation, limitation of taxation, and limitation of indebtedness prescribed in the Constitution or any statute."27

Thus, by providing the machinery of state equalization, the Butler Program legislation eliminated most of the inconsistencies and inequities arising as a result of inter-county variation in assessment ratios. It did not, however, in any way change the process or the goal of original assessment or of revision by local boards of review. The only purpose of the Butler Program was to provide a method of executing the full valuation standard in existence since I927 on a county average basis. This purpose would be realized when the assessments in each county throughout the state were equalized at a uniform average ratio of Ioo per cent of actual value. For this reason the 1945 reforms do not in any way reach whatever intra-county discrepancies may exist because of faulty assessing procedures, inter-class disparities, or geographical variations within and between townships. 28

The validity of the state equalization program has been challenged on several

5I3). Enactment of Senate Bill $3 \mathrm{I}_{4}$ and some eighty-five companion measures, providing for a downward revision of tax-rate limits, was made necessary because of the fact that Senate Bill 229, by raising the level of local assessments to full value, would, by itself, allow for substantial increases in local taxes.

22 Ill. Rev. Stat. (1947) c. $120, \$ 627$ (italics added).

$$
\begin{array}{ll}
28 & \text { Ibid., } \$ 632 . \\
24 \text { Ibid., } \$ 642 . & { }^{25} \text { Ibid., } \$ 632 .
\end{array}
$$

27 Ibid. (italics added).

${ }^{28}$ To promote uniformity in individual assessments, the Butler legislative committee had recommended an additional measure, Senate Bill 208, providing for mandatory standardized appraisal systems and for the appointment in each county of a supervisor of assessments with broad powers of control over individual assessments in his county. This bill failed of enactment because of opposition from local officials and citizens. Allen, Full-Value Assessment Program in Illinois, 3 I Bull. Nat'I Tax Ass'n II6, IIg (I946). 
grounds. In People v. Albert ${ }^{29}$ the taxpayer argued that the Butler laws provide for a determination of assessed values by the Department of Revenue and thereby contravene the Illinois constitutional provision ${ }^{30}$ that only persons authorized by the General Assembly shall place the value upon property to be taxed. According to the taxpayer, assessors and boards of review are the only legal entities established for the purpose of valuing real estate. The implications of this contention are, of course, erroneous: first, because the equalizing function of the department was conferred upon it by the General Assembly; and second, because the Butler Program equalization is not assessment valuation since it does not determine or change the proportionate allocation of the total tax bill within the particular assessing jurisdiction. The Illinois Supreme Court, in rejecting the taxpayer's argument, pointed out that the General Assembly has the power to determine the method by which property may be valued for tax purposes so long as it complies with the ad valorem requirement of the constitution, that every person or corporation pay a tax in proportion to the value of his, her, or its property. ${ }^{31}$

In People v. Albert the taxpayer also contended that the raising of the assessed valuation of property by the Butler Program machinery violated procedural due process in that the taxpayer was given no notice or opportunity to be heard with respect to the Department of Revenue's determination of the equalizing multiplier, or of the application of the multiplier by the county clerk to the original assessment as revised by the board of review. Relying upon wellestablished precedents, ${ }^{32}$ the Illinois Supreme Court distinguished between an increase of an individual assessment, which is personal and requires personal notice to the taxpayer, ${ }^{33}$ and the equalization of assessments, which is impersonal in that it involves a horizontal change in an entire class or area of property assessments without reference to ownership. Statutory notice in the latter case is sufficient since a requirement of personal notice to each of the large number of people whom an equalization proceeding affects would make assessment equalization "wholly impracticable and impossible" and would "prevent compliance with the constitution requiring equal taxation."34 Illinois statutory pro-

${ }^{29} 86$ N.E. 2d 237 (I949). A similar argument was made in People v. Wasson Coal Co., 403 Ill. 30,85 N.E. 2 d I82 (I949).

${ }^{30}$ Article IX, Section $I$ of the Illinois Constitution prescribes that the valuation of property for taxation shall be "ascertained by some person or persons, to be elected or appointed in such manner as the general assembly shall direct."

31 People v. Albert, 86 N.E. 2d 237 (I949), quoting from Anderson v. City of Park Ridge, 396 Ill. 235, 244, 72 N.E. 2d 210, 215 (I945); Accord: Adsit v. Lieb, 76 Ill. I98, I99 (1875).

${ }^{32}$ People v. Orvis, 3 or Ill. 350 , I33 N.E. 787 , (I922); Adsit v. Lieb, 76 Ill. I98 (I875); Bi-Metallic Investment Co. v. State Board of Equalization of Colorado, 239 U.S. 44I (I9I5); Union Pac. R. Co. v. Board of Comm'rs, 35 F. 2 d 785, 790 (CC.A. Ioth, I929), cert. den. 281 U.S. 734 (I929).

${ }^{33}$ See note 43 infra.

34 People v. Albert, 86 N.E. 2d 237, 24I (I949), quoting from People v. Orvis, $30 x$ Ill. $350,36 \mathrm{x}$, 333 N.E. 787,789 (r922). 
visions ${ }^{35}$ regarding the time and place of meeting of the Department of Revenue and the period during which the department is to act as a board of equalization of assessments were held to constitute sufficient notice of the department's equalization proceedings and of the implied right of the taxpayer to appear before and be heard by the department. ${ }^{36}$

The decision of the federal court of appeals in In the Matter of Chicago Railways $\mathrm{Co}^{37}$ was also based on the question of notice, this time, however, with respect to the original assessment. The trustee in reorganization of the Chicago Street Railways had returned a schedule of the personal property of the debtors at full value as required by the law. ${ }^{38}$ The court found that the Cook County Assessor had failed to reduce this full value schedule by the 30 per cent debasing factor prevailing in Cook County with respect to corporate tangible personal property assessments, ${ }^{39}$ and, further, that he had improperly increased the aggregate valuation by including items which were not the property of the debtors and by arbitrarily reducing the rate of depreciation claimed by the taxpayer-all this without timely notice to the taxpayer. ${ }^{40}$ The court of appeals affirmed the district court's findings that the original assessment was abritrary and discriminatory and thus in violation of the Illinois constitutional requirement of uniformity and equality, and that it was so in excess of real value as to be fraudulent. In upholding the district court's denial of the state's claim for recovery of a balance of taxes due, ${ }^{41}$ the court of appeals expressly refused to rule on any question related to the Butler laws or to the Department of Revenue's multiplier. Instead, the court reasoned that an excessively fraudulent original assessment ${ }^{42}$ coupled with lack of personal notice by

${ }^{35}$ Ill. Rev. Stat. (r947) c. I27, $\$ \$ 7,18$, and c. $120, \$ \$ 609,653$.

${ }^{36}$ People v. Albert, 86 N.E. $2 d 237$ (I949). Accord: Adsit v. Lieb, 76 Ill. I98 (I875); Bi-Metallic Co. v. Colorado, 239 U.S. 44x (I915); Baker v. Paxton, 29 Wyo. 500, 215 Pac. 257 (1923). Contra:Northwestern Bell Telephone Co. v. State Board of Equalization and Assessment, I I9 Neb. 138, 227 N.W. $45^{2}$ (I929).

${ }^{37}$ I 75 F. 2 d 282 (C.A. 7th, I949). $\quad 38$ Ill. Rev. Stat. (I947) c. I20, $\$ 528$ et seq.

80 The Illinois courts have long recognized that the statutory requirement of full-value assessment is not followed. They have therefore held that under the constitutional mandate of uniform taxation, all taxable property within a particular assessment jurisdiction must be uniformly undervalued even though the statutory requirement will thus be violated. Peoples Gas Light \& Coke Co. v. Stuckart, 286 Ill. I64, I2I N.E. 629; authorities cited note Ir supra.

${ }^{40}$ In an analogous case, People v. Commonwealth Edison Co., 376 Ill. $70,73,32$ N.E. 2d 902, 904 (I94I), the Illinois Supreme Court held that a reduction by an assessor of a claimed depreciation of personal property without inspecting the property or otherwise checking it was "arbitrary guesswork, lacking in required uniformity and amounting to fraud in law."

${ }^{41}$ In re Chicago Railways Co., 79 F. Supp. 989 (Ill., I948).

42 Although the general rule in Illinois is that assessments are not subject to judicial review, the courts have held that an assessment may be so grossly excessive as to amount to "constructive" fraud. People v. Stewart, 3I5 Ill. 25, I45 N.E. 600 (I924). The rule as to "constructive" fraud has been summarized in the following language: "[W] here the evidence clearly establishes that a gross overvaluation of property has been made under circumstances showing that the actual value of the property was not considered, and that the recognized standards 
pamphlet as required by the Illinois Revenue Act with respect to Cook County practice $^{43}$ were sufficient, under Illinois law, for denying the state's claim. Lack of notice was crucial in this case since it deprived the taxpayer of an opportunity to avail himself of the statutory remedies ${ }^{44}$ available for the correction of discriminatory and fraudulent assessments.

The taxpayer in the Chicago Railways case had also challenged the propriety of applying the Department of Revenue's equalizing multiplier to personal property assessments, claiming that the exclusive use of real estate transfer data in the derivation of the multiplier invalidated its application to personal property valuations and produced an equalized assessment that had no relation to the actual value of the personal property. This attack is related to the stand of the taxpayer in People v. Wasson Coal Co., ${ }^{45}$ although in that case no complaint was made with respect to either the original assessment of real estate or the derivation of the multiplier, the taxpayer claiming only that application of the multiplier to the original assessment increased the valuation

by which the value of the property is determined were not taken into consideration or applied in fixing the valuation of the property, the valuation for assessment so fixed is subject to review by the courts." People v. Wilson, 367 Ill. 494, 497, I2 N.E. 2d 5, 6 (I937).

As has been observed by one writer, "It is impossible to draw any general conclusions as to what the court will or will not consider to be overvaluation gross enough to constitute constructive fraud. About all that can be done is to indicate what has been done in the past and let the figures speak for themselves." The Illinois Constitutional Requirement of Uniformity in Tazation, 33 III. L. Rev. 57, 68 n. 60 (1938). Cases going both ways, and the amounts at issue, are collected in the latter citation. The author's statement that "proof of actual fraud has today been largely supplanted by an inquiry as to the degree of overvaluation," is borne out by the approach of the Supreme Court in the recent case of People v. Turk, 39x Ill. 424, 63 N.E. 2d 5 I3 $_{3}$ (1945).

${ }^{43}$ The Illinois Revenue Act provides for publication of assessments by newspaper or in pamphlet form. Ill. Rev. Stat. (I947) c. I20, $\$ \$ 584-85$. In cities of more than 500,000 population, the statute contemplates publication by pamphlet, directing that a copy of the pamphlet be mailed by the county assessor to every person listed therein. Ibid., $\$ \$ 589,597$. Strict compliance with all such notice provisions is considered to be of the utmost importance since actual or constructive notice in time to seek relief are essential to due process. Where a board of assessors deliberately and intentionally refused to publish an assessment list whereby the taxpayer would have been provided with constructive notice of the amount at which his property was assessed, the Illinois Supreme Court held that a court of equity might enjoin the "fraudulent" assessment there involved since the assessing authorities had defeated the taxpayer's remedy of administrative appeal. Aldrich v. Harding, 340 Ill. 354, I72 N.E. 772 (I930). And in Carney v. People, 2 Io Ill. 434 , 7 I N.E. 365 (1904), it was held that whereas constructive notice by publication of the list of original assessments plus provision for a hearing before a board of review met the due process requirement, personal notice plus an opportunity to be heard is essential in the case of an original assessment by the board of review of omitted property since the published list of original assessments gave no notice to a taxpayer whose property was omitted. Likewise, after a taxpayer's valuation has been accepted by an assessor, any increase in the valuation by a supervisor of assessments, St Louis Merchants' Bridge Co. v. Eisele, $26_{3}$ Ill. 50, IO4 N.E. IOr3 (I9I4), or by a board of review, Cox v. Hawkins, I99 Ill. 68, 64 N.E. Io94 (IgO2), requires personal notice.

44 The Illinois Revenue Act provides for review of original assessments by the board of review upon complaint that an assessment is incorrect. $I 11$. Rev. Stat. (x947) c. I20, $\$ \$ 589,594$.

${ }^{45} 403$ IIl. 30,85 N.E. 2 d I82 (I949). 
far beyond its full fair cash value. The Illinois Supreme Court disposed of this attack by pointing out that since all assessments in the county had been multiplied by the same multiplier, the complainant's equalized assessment bore the same relation to all other equalized assessments within the county as had obtained before the application of the uniform multiplier and that, therefore, the taxpayer's relative tax liability position had not been prejudiced by the Butler Program equalization process. The fault, if any, was in the original assessment and the taxpayer's right to a hearing was thus limited to the period allotted by statute for appeals to the board of review.

Left unanswered by the foregoing opinion is the question raised by the taxpayer in the Chicago Railzeays litigation; that is, whether a multiplier derived exclusively from real estate data may properly be applied in equalizing personal property assessments. The federal district court had held that where the application of such a multiplier to personal property values resulted in an excessive equalized assessment, the tax on the excess over full fair cash value was invalid. ${ }^{46}$ As pointed out above, the court of appeals refused to rule upon any issue related to the Butler Program or the Department of Revenue's multiplier, but instead rested its decision upon lack of notice with respect to a discriminatory and fraudulent original assessment. ${ }^{47}$ In the Wasson Coal Co. case, the Illinois Supreme Court noted the decision of the district court in the Chicago Railways case, but distinguished it as involving an equalization of personal property. ${ }^{48}$ Actually, however, application of a multiplier derived from a sample of real estate values to personal property is no less valid than its application to assessments of realty. The multipliers certified by the Department of Revenue to county clerks are the reciprocals of local assessment ratios determined by a sampling technique known as the real estate sales-ratio method. ${ }^{4 \theta}$ This method uses ratios obtained by comparing the assessed values of particular parcels of realty to their sales prices as disclosed by county records of bona fide sales. A basic assumption underlying the use of this method is that real estate which is bought and sold on the market is fairly representative of all property subject to assessment. ${ }^{50}$ Since the sample does not include any items of personal property, it cannot be said to furnish any direct indication as to the average assessment ratio applicable to personalty. For the same

${ }^{46} 79$ F. Supp. 989 (I11., 1948).

47 In the Matter of the Chicago Railways Co., I75 F. 2d 282 (C.A. 7 th, 1949).

${ }^{48} 403$ Ill. 30,4085 N.E. $2 \mathrm{~d}$ I82, I87 (I949).

19 Illinois Property Tax News Letter No. 4, at I4 (Ill. Dept. of Rev., Prop. Tax Div., June I948); Stiles, op. cit. supra note $I 7$, at 42 . Of the three possible measurements of nonuniformity, viz., sales ratios, appraisal ratios, and capitalized earnings ratios, the sales-ratio method, supplemented perhaps by some expert appraisals, seems to be the most practical for purposes of state equalization because of its features of objectivity and administrative feasibility. The sales-ratio method is discussed in Mitchell, Using Sales Data to Measure the Quality of Property Tax Administration, I Nat. Tax J. 330, 333 (I948); Stiles, op. cit. supra note I7, at 4I-43; IIl. Tax Comm'n, Tax Rate Limits and Assessment Ratios: I925-I940, at 2-13 (1940).

${ }^{50}$ Stiles, op. cit. supra note 17 , at 42 . 
reason, it is subject to some attack as an over-all index of the level of county assessments. However, inasmuch as real estate far exceeds personalty in the local tax base, ${ }^{51}$ whatever error results from deriving an over-all county average ratio from real estate data is, probably, at least from a pragmatic point of view, not statistically significant for purposes of state-wide equalization. ${ }^{52}$

The question of whether the real estate sales-ratio method adequately estimates the average county assessment ratio is to be distinguished from the question in the Chicago Railways case as to whether application of an equalizing multiplier derived exclusively from real estate transfer data to a tangible personal property assessment operates to prejudice the relative tax liability position of the taxpayer. A consideration of the interrelation of assessments, tax rates, and tax charges indicates that the answer to the latter question is a definite "no." A uniform tax rate is computed by the county clerk by dividing each levy ${ }^{53}$ amount, after allowing for loss and cost, by the aggregate assessed valuation of property in the particular taxing district. ${ }^{54}$ In extending taxes the county clerk multiplies each assessment by the uniform tax rate and thus determines the amount of taxes to be charged against each item of property. Prior to the Butler laws, the county clerk extended taxes on assessed valuations as equalized by the county board of review and on railroad and capital stock assessments made and certified by the Department of Revenue. ${ }^{55}$ Under the current statutory provisions the county clerk, before extending the tax, applies the multiplier certified by the Department of Revenue to each individual assessment as equalized by the county board of review. The effect of this operation is to increase the aggregate assessment to be divided into a given tax levy in computing the tax rate, thereby obtaining a tax rate lower than that which would have resulted had no multiplier been used. However, extension of

51 In 1947 , real estate represented approximately 80 per cent and personalty approximately 20 per cent of the total property tax base in Illinois subject to state equalization. These percentages are derived from statistics published in Illinois Property Tax News Letter No. 5, at Ir, AIr (IIl. Dept. of Rev., Prop. Tax Div., Feb. r949).

52 This statement is made particularly in view of the practical problems involved in obtaining objective assessment ratios of many types of personal property and in view of the confusion in local assessment policies concerning the taxation of personalty. In some counties, notably Cook, the effort to reach intangibles has led to publicly promulgated "de facto" classification whereby intangibles are assessed at lower percentages of full value than other kinds of property. IIl. Dept. of Rev., Tllinois Assessors' Manual 162-63 (1944); Ill. Tax Comm'n, Tax-Rate Limits and Assessment Ratios: $1925-1940$, at I5 $^{-19}$ ( $\left(\mathrm{r}_{940}\right.$ ). See note 6 supra on the constitutional question concerning property classification in Illinois.

${ }^{53}$ The tax levy is the amount of money that the corporate authorities of a taxing district have voted as the amount they desire to have raised for the current year from property taxes spread against the assessed valuation of property within that taxing district. IIl. Tax Comm'n, Tax-Rate Limits and Assessment Ratios: r925- I940, at 23 (1940).

${ }^{64}$ If the computed rate should exceed the legal rate limit imposed by statutes restricting the local taxing power, only the statutory maximum rate may be extended even though this will yield less than the levy amount. Ill. Rev. Stat. (I947) c. I20, \& 643; Ill. Tax Comm'n, Tax-Rate Limits and Assessment Ratios: I925- I940, at 29 (I940).

${ }^{55}$ IIl. Tax Comm'n, Tax-Rate Limits and Assessment Ratios: I925-I940, at 30 (I940). 
this uniform lower tax rate to a series of individual assessments, each uniformly increased by a constant multiplier, yields exactly the same amount of tax liability with respect to each assessment, disregarding any effect of tax rate limits, as that which would be obtained by extending against each original assessment the higher tax rate which would have resulted had the aggregate of the original assessments been divided into the same amount of tax levy. This would hold true no matter how the uniform multiplier had been derived and regardless of its relation to the assessments to which it might be applied.58 The application of any constant multiplier to each individual assessment will magnify in an absolute sense any disparity in individual assessments, but it will not change the proportionate liability of one assessment to another or to the county average. .7

The rationale of the Wasson Coal Co. case is thus equally applicable to real or personal property assessments. The assessment issue, in any case in which it is argued that an assessment, as equalized under the Butler Program machinery, is in excess of full fair cash value, reduces to a question of whether the original rather than the equalized assessment represents a fair valuation in relation to all other original assessments in the taxing district. It would thus appear that, had the Court of Appeals chosen to rule on the Butler Program in the Chicago Railways case, the disposition of the case should have been the same-an inquiry into the facts of the original assessment.

\section{VOTING TRUSTS UNDER THE ILLINOIS BUSINESS CORPORATION ACT}

Section 3 oa of the Illinois Business Corporation Act permits the use of voting trusts in the management of corporations, ${ }^{1}$ but limits the duration of such trusts

\footnotetext{
${ }^{56}$ It should be observed, however, that this identity of tax charges results only where all assessments have been equalized by the same constant multiplier. It does not, therefore, necessarily obtain in the case of a taxing district which overlaps two or more county boundaries or in the relative distribution of taxes as between state-assessed and locally assessed property. But, as has been observed, the Butler Program was designed to effect changes in just these instances by eliminating the variation in average assessment levels as between counties and as between locally assessed and state-assessed property.

${ }^{57}$ The Full-Value Assessment Program: An Analysis of the Butler Program, a report prepared by the Committee of the Ill. State's Att'ys Ass'n in collaboration with the Ill. Dept. of Rev., at 5 (1946).

1 The constitutionality of voting trusts in Illinois is not settled. Article XI, Section 3 of the Illinois Constitution requires that each stockholder have the right to vote for directors, and in Luthy v. Ream, 270 IIl. I7O, IIO N.E. 373 (19r5), the Illinois Supreme Court held that voting trusts separate stock ownership from corporate control and are thus repugnant to the constitutional provision. However, the Supreme Court in two subsequent cases distinguished Luthy v. Ream on the grounds that there is no separation of ownership from control where a corporation issues stock directly to voting trustees instead of to the stockholders who then confer them upon the trustees. Rittenberg v. Murnighan, 38 I Ill. 267, 44 N.E. 2d 9I3 (I942);
} 